\title{
Allelopathy and its Effect on Fruit Crop-A Review
}

\author{
Shaili Kumari*, Subhash Chander, Kaluram and S. Sajana \\ Division of Fruit Crops, ICAR-IIHR, Hesaraghatta, Bengaluru, 560089, Karnataka, India \\ *Corresponding author
}

\section{A B S T R A C T}

\begin{tabular}{|c|c|}
\hline & $\begin{array}{l}\text { Allelopathy defined as the harmful effect of chemical released by one plant or } \\
\text { microorganism on another plant or microorganism. Interaction among species through the } \\
\text { release of chemicals and these chemicals are recognized as allelochemicals. These are } \\
\text { released by various processes volatilization, root exudation, leaching and decomposition of }\end{array}$ \\
\hline Keywords & $\begin{array}{l}\text { and auto-inhibition. In fruit crop many allelochemicals was identified like mangiferin in } \\
\text { mango, hydroiuglone in black walnut. kavin. vagonin, dihydromethysticin and coumarin in }\end{array}$ \\
\hline $\begin{array}{l}\text { Allelopathy, Fruit } \\
\text { crop, Chemical. }\end{array}$ & $\begin{array}{l}\text { passion fruit, epicatechin, procyanidin A2, kaempferol-3-0-galactose and 4- } \\
\text { hydroxybenzaldehyde in litchi, zizynummin, dammarane and saponin in ber. Allelopathic }\end{array}$ \\
\hline Article Info & compounds released from different fruit crops have both stimulatory as well as inhibitory \\
\hline $\begin{array}{l}\text { Accepted: } \\
\text { 10 October } 2017 \\
\text { Available Online: } \\
10 \text { December } 2017\end{array}$ & $\begin{array}{l}\text { fruit, litchi leaves), inhibition of seed germination and seedling growth (compounds from } \\
\text { Black walnut, jamun, aonla and ber) and increase in soil microbial population around the } \\
\text { rhizosphere (coconut), when they are planted closely. Allelochemicals are also used to } \\
\text { treat venous insufficienciency and haemorrhoidal symptomatology. Allelochemicals, }\end{array}$ \\
\hline & $\begin{array}{l}\text { juglone having a maximum potential as a specific bactericidal effects on E. amylovora, } \\
\text { which is causal organism of fire blight in apple. Allelopathic influence of fruit crop shows } \\
\text { both inhibitory and stimulatory effect on other living organism, which needs further } \\
\text { studies for their beneficial effect in agriculture ecosystem. }\end{array}$ \\
\hline
\end{tabular}

\section{Introduction}

Allelopathy has become one of the most debatable topics among ecologist. The definitions and terminology has been both inexplicit and rigid. It takes into the account of the chemicals exudes from the plants and its effect on other plants and microorganism. It can also be defined as the harmful effect of chemical released by one plant or microorganism on another plant or microorganism (Willis, 1994)."Hans Molish" an emeritus professor of plant physiology coined the term allelopathy. The term allelopathy was coined way back in 18561937 by Hans Molish ("father of allelopathy"). The term allelopathy is the combination of two Greek word allelonmeaning mutual and pathos meaning harm and overall meaning, the mutual influences, which may be stimulatory or inhibitory of one plants or microorganism to another. According to Whittaker and Feeny (1971) allelopathic substances not only play an important function in plan communities but also project as relationship builder among 
other major group of organisms. He also introduced the more global term allelochemicals, which describes common species interaction through the release of chemicals. Grummer's scheme of allelopathic interactions specify the inter-organism relationship of allelopathic substances i.e., choline is an inhibitor or toxin produced by a higher plant, which affect another higher plant, phytoncide is in Grummer's sense a substance produced by a higher plant which suppresses microorganisms and macro fungi and marasmin substance produced by microorganisms which suppress the growth of higher plant. Antibiotic releases by microorganism which suppress the growth of another microorganism. They compared both plant form and function, particularly in relation to nutrition. The root exudation may play a role in plant system as suggested by Dutchman Boerhoove. Stephen Hales feels that root exudates facilitated excretion of used compounds. The concept of allelopathy is based on theory of root excretions. The plant interaction theory via root excretions was developed by Swiss botanist Auguste Candolle being influence of available information on phytochemistry. Interest in the concept of allelopathy was regenerate at the close of the nineteenth century, mainly for two reasons. The first was that careful agricultural experiments yielded results that could not adequately be explained by the exhaustion of soil nutrients. Secondly, improved techniques in chemistry allowed organic toxins to be identified from unproductive soils. In this regard one of the best documented plant is American black walnut (Juglans nigra), which has poisonous effect on other plant (Jose, 1998). Apart from this allelopathy effect is reported in mango, jamun, passion fruit, ber, aonla, coconut. Allelopathic effect of this crop observed in two ways allo-inhibition (chemical substances released by one species may inhibit another species) and auto-inhibition (toxins may inhibit more strongly plant of the producer species itself).

An experiment carried out by Oudhia et al., (2001) studied the allelopathic activity of guava, lemon, mango and papaya leaf extracts on emergence and seedling growth of Lathyrus. Inhibitory effect on Lathyrus emergence was observed from guava and mango while lemon and papaya leaf extracts have no harmful effect on Lathyrus emergence.

\section{Allelochemicals - occurrence and distributions}

Allelochemicals may be defined in a relative manner as a non-nutritive chemicals produced by one plant or organism that affect the growth, health, behaviour, or population biology of members of other species. According to Putnam and Tang (1986), all alleged cases of allelopathy that have been studied appear to involve a complexity of chemicals. No single phytotoxin was solely responsible for or produced as a result of interference by a neighbouring plant. Rizvi et al., (1992) pointed out that the subject not only deals with the gross biochemical interactions and their effects on the physiological processes but also with the mechanism of action of allelochemicals at specific sites of action at the molecular level. Rice (1984) and Putnam (1985) accounted that allelochemicals are almost found in all plant tissue, i.e. leaves, fruit, stems, and roots. These are then released by various processes volatilization, root exudation, leaching and decomposition of plant residues. The most stable sources reported so far is leaves, while roots are considered to contain fewer and less potent toxins. They must be concentrated in the leaves, stem or roots rather than in the fruit or flowers. If it is concentrated in these organs, it is unlikely that it could be available in time to interfere with neighbouring plants 
(Aldrich 1984). According to Rice (1984) and Putnam (1985), there are four ways in which the chemicals are released: Volatilization L, release into the atmosphere. It is only significant under arid or semi-arid conditions. The compounds may be absorbed in vapour by surrounding plants, be absorbed from condensate in dew or may reach the soil and be taken up by the roots. Leaching L, rainfall, dew or irrigation may leach the chemicals from the aerial parts of plants that are subsequently deposited on other plants or on the soil. Leaching may also occur through plant residues. Their solubility will affect their mobility in soil water. Root exudation L, from plant roots into the soil environment. Whether these compounds are actively exuded, leaked or arise from dead cells sloughing off the roots is not clearly understood at this time. Decomposition of plant residues $\mathrm{L}$, it is difficult to determine whether toxic substances are contained in residues and simply released upon decomposition, or produced instead by microorganisms utilizing the residues. Whittaker and Feeney (1971), Rice (1984) and Putnam and Tang (1986) divided allelochemicals into various major chemical groups: Simple watersoluble organic acids, simple unsaturated lactones, long-chain fatty acids and polyacetylenes, naphthoquinone, anthroquinones and complex quinines, simple phenols, benzoic acid and derivates, cinnamic acid and derivates, flavonoids, tannins, terpenoids and steroids, amino acids and polypeptides, alkaloids and cyanohydrins, sulphides and glucosides, purines and nucleotides, coumarins, thiocyanates, lactones and actogenins.

\section{Mode of action}

There are two types of allelopathy i.e., direct and indirect allelopathy- If one plant or microorganism inhibit or stimulate the growth of another plant or microorganism without involvement of another mediator called direct allelopathy or primary allelopathy, but in case of indirect allelopathy or mediated allelopathy an intermediate organism is involved. The mode of action of a chemical can broadly be divided into a direct and an indirect action (Rizvi et al., 1992). Effects through the alternation of soil properties, nutritional status and an altered population or activity of microorganisms and nematodes represent the indirect action. The direct action involves the biochemical/physiological effects of allelochemicals on various important processes of plant growth and metabolism. Processes affected by allelochemicals are; mineral uptake i.e., allelochemicals can alter the rate at which ions are absorbed by plants. A reduction in both macro and micronutrients are encountered in the presence of phenolic acids (Rice, 1974). Cytology and ultrastructure a variety of allelochemicals have been shown to inhibit mitosis in plant roots (Rice, 1974). Phytohormone and plant growth hormones like indole acetic acid (IAA) and gibberellins (GA) regulate cell enlargement in plants. IAA is present in both active and inactive forms, which is inactivated by IAA- oxidase. IAA- oxidase is inhibited by various allelochemicals (Rice, 1974). Other inhibitors block GA-induced extension growth. Membranes and membrane permeability many biological compounds exert their action through changes in permeability of membranes. Exudation of compounds from roots on root slices have been used as an index of permeability because plant membranes are difficult to study (Harper and Balke, 1981). Photosynthesis photosynthetic inhibitors may be electron inhibitors or uncouplers, energy-transfer inhibitors electron acceptors or a combination of the above (Einhellig and Rasmussen, 1979; Patterson, 1981). Respiration allelochemicals can stimulate or inhibit respiration, both of which can be harmful to the energy producing process (Rice, 1974). Protein synthesis L 
studies utilizing radio-labelled $\mathrm{C}^{14}$ sugars or amino acids, and traced incorporation of the label into protein, found that allelochemicals inhibit protein synthesis (Rice, 1974). Rice (1984) reported Specific enzyme activity, on a number of allelochemicals that inhibit the function of enzymes in the plant conducting tissue (Rice, 1974), water relations (Rice, 1974) and genetic material (Rice, 1984, Aldrich, 1984). Under natural conditions the action of allelochemicals appears to be organised by a fine-tuned regulatory process where various compounds may act together on one or more of the above processes (Rizvi et al., 1992).

\section{Allelopathic Compound and Their Role in Fruit Crop}

In fruit crop many allelochemicals was identified which are listed in Table 1, Mangiferin in mango, hydrojuglone in black walnut, kavin, yagonin, dihydromethysticin and coumarin in passion fruit, epicatechin, procyanidin A2, kaempferol-3-0-galactose and 4-hydroxybenzaldehyde in litchi, zizynummin, dammarane and saponin in ber. These are example of allelochemicals which basically found in fruit crop. Different allelochemicals are defined for different fruit crops. These allelochemicals show inhibitory and beneficial effect on different fruit crops according to their mode of action. According to their effect on other plant these allelochemicals plays important role in fruit production system. Some allelochemicals used as natural herbicides for weed management and it also enhanced the seed germination of annuals.

\section{As natural herbicides}

Mangiferin: Allelopathic compounds, which are extracted from mango (Mangifera indica L.) leaves, are used for weed management in rose basins. The allelopathic compound was identified as mangiferin which is basically 1 , 3, 6, 7-tetra hydroxyl 2-C-Bglucopyranosylxanthone. Experiment was conducted to show the allelopathic activity of mangiferin at different concentrations on wheat, radish and okra seeds. At concentration of 200ppm mangiferin did not show any effect on germination of radish, wheat, okra. Leaf chlorophyll formation was suppressed at 200ppm in radish, wheat and okra. In comparison of young leaf, old mango leaves extract was found most effective in wheat germination and growth. Young leaf extract reduced shoot length and grain weight of wheat. This indicated that total phenolic contents were more in new mango leaves as compared to old ones (Venkateshwarlu et al., 2001). Phenolic compounds 4hydroxybenzaldehyde, $m$-coumaric, $\quad p$ coumaric, 4-hydroxy benzoic, vanillic, caffeic, gallic and protocatechuic acids were identified through Mass Spectrometry and High Performance Liquid Chromatography in mango leaves. It was observed that leaves extract of old mango leaf could be used as herbicide to suppress the canary grass and enhance the germination of wheat (Saleem et al., 2013). In another study is bioassay and greenhouse studies of allelopathic effect of passion fruit on germination and growth of indicator plants of paddy [barnyardgrass (Echinochloa crusgall), monochoria(Monochoria vaginallis), radish (Raphanus sativus) and lettuce (Lactuca sativa)] and major paddy weeds. In field's trial, the plants materials of passion fruit applied at 1-2 tones/ha, it increased rice yield by $30 \%$ and reduced the initial growth of paddy weeds by $70 \%$. Allelopathic properties vary in different plant part of passion fruit, followed as the order: leaf $>$ stem $>$ roots. Various chemical substances, which belonging to alkaloids, phenolics, flavonoids and volatiles were found in passion fruit; these are kavin, yagonin, dihydromethysticin and coumarin. These allelochemicals completely suppressed 
the barnyard grass growth at $500 \mathrm{mg} / \mathrm{l}$ concentrations so it may be used as a natural herbicide in place of synthetic herbicides and other agrochemicals, which is injurious to human health and environment (Khan et al., 2008). The allelopathic potential of Litchi chinensis utilises as natural herbicide in the field. Leaf extracts of litchi tree applied on test weeds, which slow down the radicle growth of it (Islam et al., 2013). Chromatography, mass analysis and NMR spectroscopic analysis identified epicatechin, procyanidin A2, Kaempferol-3-0-galactose and 4-hydroxybenzaldehyde as an allelopathic compound in litchi. Litchi leaf powder reduced the growth of weeds including Bidens pilosa, Eleusine indica, and Portuiaca oleracea, which further reduce their competition with main crop.

It shows that beneficial usage of litchi leaf as natural herbicides. In another study Terminalia catappa (tropical almond) fruit or leaf extracts were applied to the weeds $E$. heterophylla and $C$. bengalensis. Allelopatic compound was identified as dichloromethane and ethyl-acetate. Allelochemical potential of T. catalpa is highest in fruit extract compared to leaf extract. It suppresses the growth of weeds $E$. heterophylla and $C$. bengalensis (Baratelli et al., 2012).

Table.1 Allelopathic effect on fruit crop

\begin{tabular}{|c|c|c|}
\hline Crop & Allelochemicals & References \\
\hline Mango & $\begin{array}{l}\text { Mangiferin (1,3,6,7-tetra hydroxyl 2-C-B- } \\
\text { glucopyranosylxanthone) }\end{array}$ & $\begin{array}{l}\text { Venkateshwarlu et } \\
\text { al., (2001) }\end{array}$ \\
\hline & $\begin{array}{l}\text { 4-hydroxybenzaldehyde, } m \text {-coumaric, } p \text {-coumaric, } \\
\text { 4-hydroxy benzoic, vanillic, caffeic, gallic and } \\
\text { protocatechuic acids }\end{array}$ & Saleem et al., (2013) \\
\hline Black walnut & $\begin{array}{l}20 \% \text { methanol, ethyl acetate and hexane n- } \\
\text { Hexadecanoic acid, 9,12-octadecadienoic acid } \\
\text { (Z,Z), 8-octadecenoic acid and 5-hydroxy-1,4- } \\
\text { napthaquinone } \\
\text { Hydrojuglone }\end{array}$ & Cui et al., (2011) \\
\hline Passion fruit & Kavin,Yagonin,Dihydromethysticin and Coumarin & Khanh et al., (2008) \\
\hline Litchi & $\begin{array}{l}\text { Epicatechin, ProcyanidinA2, Kaempferol-3-0- } \\
\text { galactose and 4-Hydroxybenzaldehyde }\end{array}$ & Islam et al., (2013) \\
\hline Ber & Zizynummin, Dammarane, Saponin & Saroj et al., (2000) \\
\hline $\begin{array}{l}\text { Tropical } \\
\text { almond }\end{array}$ & Dichloromethane and Ethyl-acetate & $\begin{array}{l}\text { Baratelli et al., } \\
(2012)\end{array}$ \\
\hline
\end{tabular}

\section{Allelopathic effect on seed germination}

Earliest report suggestions show that many fruit crop release a substances, which is harmful to other organisms. Its best example has been seen in walnut. Allelopathic effect around tree rhizosphere was observed. Experiment shows that extracts of walnut rhizosphere repressed the seed germination and growth of cabbage seedling. This result shows that the presence of inhibitory compounds in the rhizosphere of walnut trees, which shows the allelopathic effects on cabbage (Cui et al., 2011). N-Hexadecanoic acid, 9, 12-octadecadienoic acid (Z, Z), 8octadecenoic acid and 5-hydroxy-1,4napthaquinone are important allelochemicals, which is usually found around walnut tree 
rhizosphere soil. The root exudates of walnut trees were extracted with the neutral, acidic, and alkaline medium of ethyl acetate. These exudates of ethyl acetate were used to see the effect on enzymatic activities, germination and seedling growth of turnip. Ethyl acetate extract shows inhibitory effect on seed germination and seedling growth of turnip. The result shows that black walnut is most notorious allelopathic tree. Its plant release a non-toxic colourless chemical compounds, which is known as hydrojuglone. The above result shows that black walnut allelopathy affected most adversely on growth of vegetables, field crops, ornamental plants and several woody species (Cui et al., 2012). Allelopathic influence of aqueous leaf extracts of ber on germination, seedling growth and seedling phytomass of ground storey crops viz. groundnut, cluster bean, wheat and mustard under laboratory conditions was observed. The result shows that allelochemicals found in ber leaf extract is water-soluble which shows maximum inhibitory effect on mustard and minimum on cluster bean.In response to allelochemicals other crops showed variable response by exhibiting sensitivity in one character and tolerance in another character (Saroj et al., 2000). Effect of aqueous leaf extract of ber (Ziziphus mauritiana) on seed germination and seedling growth of cowpea (Vigna unguiculata) and fenugreek (Trigonella foenumgraecum) was studied. These experiment shows that the aqueous leaf extracts of ber inhibit the germination of both the crop cowpea and fenugreek, but its effect was higher in fenugreek. The Inhibitory effect was more pronounced in fenugreek as compared to cowpea which indicated the sensitivity of fenugreek in response of allelochemicals present in aqueous extracts of ber leaves (Saroj et al., 2009).

Aonla leaf extracts also shows allelopathic effect on germination and seedling growth of moth bean (Phaseolus acontifoius), wheat ( $T$. aestivum), gram (Cicer arietinum) and mustard (Brassica campestris). Seed germination of mustard is reduced upto $6 \%$ in comparison of other crops. While minimum allelopathic effect of Aonla leaf extract on seed germination was noticed in wheat $(90 \%)$ and moth bean (100\%), respectively. Different response of aonla leaf extract on different seedling growth is as follows. Shoot growth is more as compared to root growth, it was recorded that $>50 \%$ reduction in shoot growth in mustard, followed by $32.43 \%$ in gram. The other seedling growth parameters like number of roots, number of leaves /plant, root: shoot ratio and vigour index also followed the same trend. Water soluble allelochemicals of aonla had utmost inhibitory effect on mustard and least on moth bean and wheat with respect to seedling germination, seedling vigour and seedling phytomass (Awasthi et al., 2009). Jamun pulp contains allelochemicals which shows Allelopathic effects on rice, maize and green gram crops. The pulp extract of jamun significantly inhibit the seed germination, seedling growth and biomass yield of rice, maize and green gram in both bioassay and pot culture. The test crop rice (Oryza sativa) was more vulnerable in comparison of maize (Zea mays). The pulp extract reduced the germination $22.2 \%$, shoot length $28.1 \%$ and biomass yield by $32.5 \%$ respectively. When rice grows underneath the jamun tree, it significantly reduces the yield. The inhibitory effect of pulp extract of jamun followed the order: $O$. sativa $>Z$. mays $>V$. radiate (Bhatt et al., 2011). The allelopathic potential of dry and fresh coffee fruit peel extract on lettuce, Malaysian cabbage and beggar's tick seeds and seedlings was evaluated. Allelopathic effect of coffee extract was recorded at pre-emergence, postemergence and at mitotic index of meristematic root cell formation. Allelopathic activity of coffee fruit extract reduced the size of the primary root of the lettuce, Malaysian 
cabbage and beggar's tick seedlings. It was observed that coffee fruit is capable of interfering with the development and stabilization of other species (Selva et al., 2013).

\section{Allelopathic Potential of Fruit Crop on Growth and Yield of Intercrop and in Soil Fertility Improvement}

Allelochemicals influence plant growth and development which further decide the final yield of tree. Roots of the fruit tree release various allelochemicals in its rhizosphere which shows its effect on the adjoining crops. Juglone is allelochemicals found in leaf extracts of Persian walnut (Juglans regia L.), which shows allelopathic influence on yield, growth, chemical and nutritional composition of the strawberry cultivar Fern. In this experiment strawberry plants were treated with juglone (5-hydroxy-1.4 naphthoquinone, $1 \mathrm{mM}$ ) and walnut leaf extracts (undiluted, 1:2, 1:4, 1:8 diluted). Juglone and undiluted walnut leaf extracts both inhibited vegetative and reproductive plant growth. It reduced fruit yield per plant, number of fruit per plant, average fruit weight, crowns per plant, number of leaves, leaf area, fresh root weight, total soluble solid (TSS), vitamin $\mathrm{C}$ and acidity in comparison to control (Ercisli et al., 2005). Ercisli and Sezai (2005) conducted an experiment in a heated greenhouse to investigate the effects of juglone (5-hydroxy1,4-napthoquinone) on yield, growth, chemical and plant nutrient element composition of short-day strawberry cultivars 'Camarosa' and 'Sweet Charlie'. Result shows that inhibition of strawberry plants growth under walnut-based intercropping systems. Murligopal et al., (2006) reported that allelopathic effects of root and leaf leachates of coconut on selected beneficial microorganisms around coconut rhizosphere. Many agriculturally beneficial microbes, phosphate solublizers and plant growth promoting rhizobacteria provide the minimal nutrition to palms. However their population and activities are affected by chemicals (tannins and phenols) released from biomass, leachates and root exudates. The leachates affected the rhizosphere micro flora in coconut based cropping system.

\section{Medicinal Use}

In plant many allelochemicals has been identified showing their medicinal value. Apart from its other agricultural importance, these chemicals also contain medicinal property for curing the disease. Walnut leaves contain allelochemicals, which have inhibitory and stimulatory effect on growth of other plant and microorganism. But in some cases this allelochemicals used for medicinal purpose, which are source of health promoting compounds utilized as traditional medicine to treat venous insufficienciency and haemorrhoidal symptomatology (Ercisli et al., 2005).

\section{Fungicidal property}

Allelochemicals are reported to have antifungal activity. They have inhibitory effect on fungal growth. A screening of fruit crop allelochemicals was done for studying the inhibiting effect of allelochemicals on the bacterial fire blight pathogen Erwinia amylovora. Among them most active compound, juglone from walnuts was identified which have maximum potential as a specific bactericidal effects on E.amylovora at lower concentration of 2.5-10 $\mu \mathrm{M}$. The same experiment was done in in vitro test with juglone and it inoculated in flowers of apple (Malus domestica), these result showed that it preventing $67 \%$ of infection. Field tests were done continuously two year at variable degrees to run the efficacy of juglone in various environmental conditions. Allelopathic influence of juglone was only 
restricted to browning of petals, later fruit rusting was not observed. Juglone is a most promising allelochemicals to control the growth of fire blight bacteria in a new environment to replace the bactericide antibiotic streptomycin for fire blight control (Fischer et al., 2012).

\section{References}

Aldrich, J. D., 1984. Weed-crop ecology: Principles and practices. Breton Publishers. 215-241.

Awasthi, O. P., Singh, I. S. and Bhargava, R. 2009. Allelopathy influences of aonla (Emblica officinalis) leaf extract on germination and seedling growth of seasonal crops, Range mgmt. and Agroforestary. 26(2):120-123.

Bhatt, B.P., Singh, J.K. Imtimongla and Moanaro. 2011. Effects of pulp extract of jamun (Syzygium cumini L) fruits on rice, maize and green gram crops. Allelopathy Journal. 27(1):143-150

Cui Cui, Jingcai, Zaimin, Jiang and Shuoxin Zhang. 2012. Isolation and identification of allelochemicals in rhizosphere and adjacent soil under walnut (Juglans regia) trees. Allelopathy Journal. 29(1): 25-36

Cui Cui, Jingcai, Zaiminjiang and Shuoxinzhang. 2011. Effect of walnut (Juglans regia L.) root exudates on germination, seedling growth and enzymatic activities of turnip (Brassica rapa). Allelopathy Journal. 28(2): 237250

Einhellig, F. A. and Rasmussen, J. A., 1979. Effects of three phenolic acids on chlorophyll content and growth of soybean and grain sorghum seedlings. Journal of Chemical Ecology. 5: 815.

Einhellig, F. A. 1987. Interactions among allelochemicals and other stress factors of the plant environment. Pp. 343-357

Ercisli, S., Esitken, A., Turkkal, C. and
Orhan, E. (2005). Allelopathic Effects of Juglone and Walnut Leaf Extracts on Growth, Fruit Yield and Plant Tissue Composition in Strawberry Cvs. 'Camarosa' and 'Sweet Charlie'. Journal of Horticultural Science and Biotechnology. 80(1): 39-40

Ercisli, S., Esitken, A., Turkkal, C. and Orhan, E. (2005). The allelopathic effects of juglone and walnut leaf extracts on yield, growth, chemical and PNE compositions of strawberry cv. Fern. Plant Soil Environ. 51 (6): 283287

Gopal, Murali, Gupta, Alka, Sunil, E. and Thomas, G. V. 2006. Allelopathic effects of roots and leaf leachates of coconut on selected beneficial microorganism. Allelopathic journal. 18(2): 363-368.

Harper, J.R. and Balke, N.E., 1981. Characterization of the inhibition of $\mathrm{K}+$ absorption in oat roots by salicylic acid. Plant Physiology. 68: 1349.

Kamran saleem, Shagufta, Perveen, Nighat sarwar, Farooq, latif, Khalid, Pervaiz Akhtar; Hafiz, Muhammad and Imran, arshadpak. 2013. Identification of phenolics in mango leaves extract and their allelopathic effect on canary grass and wheat. J. bot. 45(5): 1527-1535.

Khanh, T. D. Xuan, Linh, L. H. and Chung, I. M. 2008. Allelopathic plants: Passion fruit (Passiflora spp). Allelopathy journal. 21(2):199-206.

Oudhia, P. 2001. Evaluation of allelopathic effects of some fruit tree leaf extracts on emergence and seedling vigour of Lathyrus var. biol-212. Legume Research. 24(3):207-208.

Patterson, D.T. 1981. Effects of allelochemicals on growth and physiological responses of soybeans (Glycine max). Weed Science. 29- 53.

Putnam, A. R. and Tang, C. S. 1986. Allelopathy: State of the science. In: 
A.R. Putnam, and C.S. Tang (ed.). The science of allelopathy. Wiley, New York. 1-19.

Putnam, Alan R., and ChungShih Tang (eds.). 1986. The science of allelopathy. Wiley-Interscience Publications, John Wiley and Sons, New York. $x i+317$ p.

Regildo, M.G. Silva, João G.F. Brigatti, Valter, Santos, H.M., Gustavo, F. Mecina, Luciana, Silva, P. 2013. Allelopathic effect of the peel of coffee fruit. Scientia Horticulturae. 158: 3944.

Rice E. L., 1974. Allelopathy. Academic Press.

Rice, E. L., 1984. Allelopathy. $2^{\text {nd }}$ edition. Academic Press.

Rizvi, S.J.H., Haque, H., Singh, V.K. and Rizvi, V. 1992. A discipline called allelopathy. In: S.J.H. Rizvi, and V. Rizvi (eds.). Allelopathy: Basic and applied aspects. Chapmann and Hall Publishers. 1-8.

Saroj, P. L., and Purohit, C. K. 2009. Influence of aqueous leaf extract of ber on germination and seedling growth of cowpea and fenugreek. Agriculture Society for Recent Development in Agriculture. 9(1): 6-11.

Saroj, P. L., Sharma, B. D., Bhargava, R. and Purohit, C. K. 2002. Allelopathic influences of aqueous leaf extracts of ber (Ziziphus mauritiana). on germination, seedling growth and phytomass of ground storey crops, Allelopathy Journal. 4(1): 57-61.

Tatiana de Gouveia Baratelli, Anne Caroline Candido Gomes, Ludger A. Wessjohann, Ricardo Machado Kuster,
Naomi Kato Simas, 2012. Phytochemical and allelopathic studies of Terminalia catappa L. (Combretaceae). Biochemical Systematics and Ecology. 41: 119-125.

Thilo Christopher Fischer, Christian Gosch, Beate Mirbeth, Markus Gselmann, Veronika Thallmair, and Karl Stich. 2012. Potent and Specific Bactericidal Effect of Juglone (5-Hydroxy-1,4naphthoquinone) on the Fire Blight Pathogen Erwinia amylovora. Journal of Agricultural and Food Chemistry. 60 (49): 12074-12081.

Venkateshwarlu, Ravindra, G. V. and Challa, Prabha. 2001. Mangiferin: anallelopathin from mango (Mangifera indica L.) leaves. Allelopathy journal. 8(2): 221-224

Whittaker, R. and Feeny, P. 1971. Allelochemics: chemical interactions between species. Science. 171: 757-770.

Willia, S, C. M. and Adkisson, P. L. 1964. Physiology of insect diapause XIV. An endocrine mechanism for the photoperiodic control of pupal diapause in the oak silkworm, Antheraea peryni. BioI. Bull. 127: 511-525.

Williams, F. X. 1905. Notes on the larvae of certain Lepidoptera. Entomol. News. p. 153. Wilson, A. C., Bush, G. L., Case, S. M. and King, M. C. 1975. Social structure of mammal populations and rate of chromosomal evolution. Proc. Natl. Acad. Sci. (U.S.A.). 72: 50615065.

Wills.1994.Terminology and trends in allelopathy. Allelopathy journal. Pp. 820.

\section{How to cite this article:}

Shaili Kumari, Subhash Chander, Kaluram and Sajana, S. 2017. Allelopathy and its Effect on Fruit Crop-A Review. Int.J.Curr.Microbiol.App.Sci. 6(12): 952-960.

doi: https://doi.org/10.20546/ijcmas.2017.612.105 